Volume 3 - Number 1, May 2016, (112-121)

Available online at: http://journal.uny.ac.id/index.php/ljtp

\title{
HUBUNGAN ANTARA PENGUASAAN KOSAKATA DAN KETEPATAN MENEMUKAN GAGASAN DENGAN KETERAMPILAN MEMBACA PEMAHAMAN
}

\author{
Tjatur Marti Susilawati ${ }^{1}$, Suhardi $^{2}$ \\ ${ }^{1}$ SMP Negeri 2 Tegalrejo. Dusun Sidorejo, Karangduren, Tegalrejo Kab. Magelang, 56192, Indonesia. \\ ${ }^{2}$ Jurusan Pendidikan Bahasa dan Sastra Indonesia, Universitas Negeri Yogyakarta. Jalan Colombo No. \\ 1, Karangmalang, Yogyakarta 55281, Indonesia. \\ * Korespondensi Penulis. Email: caturmarti5 @ gmail.com, Telp: +6281392053440
}

\begin{abstract}
Abstrak
Penelitian ini bertujuan untuk mengetahui hubungan: (1) penguasaan kosakata dan keterampilan membaca pemahaman, (2) ketepatan menemukan gagasan dan keterampilan membaca pemahaman, (3) hubungan penguasaan kosakata $\left(\mathrm{X}_{1}\right)$ dan ketepatan menemukan gagasan $\left(\mathrm{X}_{2}\right)$ dengan keterampilan membaca pemahaman (Y). Penelitian ini adalah kuantitatif ex-post facto. Penentuan sampel berdasarkan teknik proportional cluster random sampling. Validitas instrumen diuji menggunakan program ITEMAN, sedangkan reliabilitas instrumen diuji dengan Alpha Cronbach. Hasil penelitian ini menunjukkan bahwa penguasaan kosakata dan keterampilan membaca pemahaman $\left(\mathrm{X}_{1}-\mathrm{Y}\right)$ memiliki hubungan positif dan signifikan dengan hasil $\mathrm{r}$ sebesar 0,613 dan $\operatorname{sig} \rho<0,05$. Hasil uji korelasi ketepatan menemukan gagasan dan keterampilan membaca pemahaman $\left(\mathrm{X}_{2}-\mathrm{Y}\right)$ terbukti positif dan signifikan dengan $r=0,641$ dan sig $\rho<0,05$. Hasil analisis korelasi parsial untuk $X_{1} \cdot X_{2}-Y$ dan $X_{2} \cdot X_{1-}$ Ysebesar 0,151 dan 0,281. Analisis regresi linear ganda menghasilkan $\mathbf{r}$ sebesar 0,651 dengan $\rho<0,05$. Pengaruh penguasaan kosakata dan ketepatan menemukan gagasan terhadap keterampilan membaca pemahaman sebesar 0,420 atau $42 \%$ dan terbukti signifikan.
\end{abstract}

Kata Kunci: penguasaan kosakata, ketepatan menemukan gagasan, kemampuan membaca pemahaman

\section{THE CORRELATION BETWEEN VOCABULARY MASTERY AND ACCURACY IN FINDING IDEAS ON THE READING COMPREHENSION SKILL}

\begin{abstract}
This research is meant to find out (1) the correlation between vocabulary mastery and reading comprehension skill, (2) the correlation between the accuracy in finding ideas and reading comprehension skill, and (3) the correlation between vocabulary mastery and the accuracy in finding ideas on reading comprehension skill. The kind of this research is a quantitative ex post facto. The sample was selected by means of proportional cluster random sampling. The instruments validity used the ITEMAN programs and the instruments reliability using Alpha Cronbach's. The results of the research show that the correlation between vocabulary mastery and reading comprehension skill $\left(X_{I^{-}}\right.$ $Y)$ is proved significant and positive, gives the result of $\boldsymbol{r}=0.613$ and $\rho<0.05$. The result of the correlation between the accuracy in finding ideas and reading comprehension skill $\left(X_{2}-Y\right)$ is proved significant and $r=0.641$, and $\rho<0.05$. The result of the partial correlation analysis for $X_{1} \cdot X_{2}-Y$ gives the result of $r=0.151$ and for $X_{2} \cdot X_{1}-Y$, was of $0.281, \rho<0.05$. The linear regression analysis gives the result of $\boldsymbol{r}=0.651$ and $\rho<0.05$. The influence of the vocabulary mastery and accuracy of finding ideas on reading comprehension skill is $0.420(42 \%)$ and is proved significant.
\end{abstract}

Keywords: vocabulary mastery, accuracy in finding ideas, the reading comprehension skill

How to Cite: Susilawati, T., \& Suhardi, S. (2016). Hubungan antara penguasaan kosakata dan ketepatan menemukan gagasan dengan keterampilan membaca pemahaman. LingTera, 3(1), 112-121. doi:http://dx.doi.org/10.21831/lt.v3i1.8796

Permalink/DOI: http://dx.doi.org/10.21831/lt.v3i1.8796 


\section{LingTera, 3 (1), May 2016 - 113 \\ Tjatur Marti Susilawati, Suhardi}

\section{PENDAHULUAN}

Pendidikan bahasa khususnya bahasa Indonesia merupakan aspek penting yang perlu dikuasai dan diajarkan pada siswa. Sesuai dengan fungsinya sebagai alat komunikasi, bahasa Indonesia diajarkan pada siswa agar mereka mampu menggunakannya dengan baik. Salah satu unsur bahasa yang perlu dikuasai siswa agar mereka dapat berkomunikasi dengan baik adalah penguasaan kosakata. Penguasaan kosakata yang memadai, akan menghambat siswa dalam penguasaan keterampilan berbahasanya, baik dalam menyimak, berbicara, membaca, maupun menulis.

Membaca sebagai salah satu keterampilan berbahasa pada dasarnya merupakan kegiatan memahami teks yang sangat penting dikuasai siswa. Agar kegiatan membaca mencapai hasil yang optimal, ada beberapa faktor yang mempengaruhi proses pemahaman bacaan. Harjasujana \& Mulyati (1997, p.60) mengemukakan faktorfaktor yang mempengaruhi proses dalam membaca pemahaman, antara lain (1) latar belakang pengalaman, (2) kemampuan berbahasa, (3) kemampuan berpikir, (4) tujuan membaca, dan (5) pengaruh motivasi, sikap, minat, keyakinan dan perasaan. Kegiatan membaca dengan tujuan memahami isi bacaan dapat diartikan bahwa ketika seseorang membaca teks yang berwujud paragraf-paragraf harus mampu memahami kalimat-kalimat yang mengungkapkan satuan informasi dengan pikiran atau gagasan utama dan gagasan penjelas sebagai pendukungnya. Kekurangmampuan dalam menemukan sebuah gagasan pokok paragraf maupun gagasan penjelas pada sebuah teks menjadi penyebab sulitnya memahami isi informasi yang disampaikan oleh teks tersebut. Pada kenyataannya, kemampuan siswa dalam menemukan gagasan sebuah paragraf masih sangat memprihatinkan. Sesuai hal tersebut, Suryaman (2012, p. 37) mengemukakan bahwa hasil penelitian PISA tahun 2003 menunjukkan bahwa 37,6\% anak-anak Indonesia hanya bisa membaca tanpa bisa memahami maknanya.

Pemakaian bahasa terutama dalam kegiatan berkomunikasi pada hakikatnya adalah pemakaian kata-kata, sehingga mengetahui, memahami dan dapat menggunakan kata-kata dengan baik merupakan modal utama dalam berbahasa. Kosakata berperan sangat penting baik dalam kegiatan berbahasa sebagai proses berpikir maupun berkomunikasi dalam kehidupan sehari-hari. Nurgiyantoro (2012, p.282) menyatakan bahwa "untuk dapat melakukan kegiatan berkomunikasi dengan bahasa, diperlukan penguasaan kosakata dalam jumlah yang memadai". Dalam kehidupannya, seseorang harus mampu menggunakan kosakatanya secara optimal.

Proses penguasaan kosakata seseorang bukan suatu proses yang spontan melainkan bertahap dimulai semenjak bayi. Proses penguasaan kosakata mencakup kemampuan (1) mengenali makna, (2) memilih suatu kata yang sesuai dengan pengertian tertentu, dan (3) menerapkan kosakata dalam konteks kalimat. Alex \& Achmad (2010, p.232) mengungkapkan tiga hal yang dapat dilakukan seseorang yang ingin memperluas kosakatanya yakni: (1) pemakaian kamus umum dan kamus sinonim yang baik, (2) pemasukan kata baru dalam tulisan dan pembicaraan, dan (3) usaha membaca jenis tulisan yang sebanyak-banyaknya untuk mencapai kosakata dan memperoleh kepekaan bahasa yang luas.

Bagi Siswa SMP, upaya untuk memperluas pengetahuan kosakatanya bisa belajar secara formal di sekolah melalui guru dengan pemilihan strategi pembelajaran kosakata yang tepat dalam kegiatan pembelajaran di kelas. Nation (2001, pp.107-108) menguraikan prosedur pembelajaran dalam upaya memperkaya kosakata siswa dapat dilakukan dengan, (1) recycled words, yaitu mengajarkan kosakata bergerak dari receptive use ke productive use yang berfokus pada belajar yang disengaja, (2) the second-hand cloze, yang terdiri atas tiga langkah yaitu siswa membaca teks mengandung kosakata sasaran, siswa dengan sengaja belajar kosakata dan diberikan cloze passages yang merupakan ringkasan apa yang sesungguhnya dibaca, (3) the vocabulary interview, yaitu memberikan kesempatan pada siswa untuk melakukan tanya jawab kepada guru atau siswa lain tentang kosakata tertentu.

Usaha peningkatan perbendaharaan kosakata dalam pembelajaran bahasa di sekolah merupakan bagian dari usaha meningkatkan pemahaman bacaan pada diri siswa pada kegiatan membaca. Dengan penguasaan kosakata yang memadai akan turut mempengaruhi pemahamannya terhadap informasi yang disampaikan suatu bacaan. Penguasaan kosakata tidak sekedar pemahaman seseorang terhadap arti kata yang didengar atau dibaca melainkan secara nyata atas prakarsa dan penguasaannya itu mampu menggunakannya dalam tindak berbahasa tertentu baik secara lisan maupun tertulis. 


\section{LingTera, 3 (1), May 2016 - 114 \\ Tjatur Marti Susilawati, Suhardi}

Memahami isi suatu bacaan berarti mampu memahami gagasan yang disampaikan dalam bacaan tersebut. Gagasan bacaan tertuang dalam bentuk paragraf yang memiliki satu gagasan pokok. Gagasan pokok dalam setiap paragraf disebut kalimat topik. Rohmadi \& Nasucha (2010, pp.22-23) mengatakan bahwa "kalimat topik itu merupakan pernyataan umum dalam suatu paragraf yang diterangkan oleh beberapa kalimat pendukung". Paragraf merupakan wadah bagi seseorang untuk menuangkan pokok pikiran atau gagasan pokok. Setiap paragraf dikendalikan oleh satu ide pokok atau gagasan pokok. Gagasan pokok biasanya dikemas dalam sebuah kalimat utama, sedangkan kalimat-kalimat yang lain berfungsi menjelaskan atau mendukungnya yang disebut sebagai kalimat penjelas. Rahardi (2009, p.158) menyatakan, bahwa "paragraf yang baik ialah tidak boleh menyisakan serpihan gagasan yang terkandung di dalam ide pokok paragraf itu". Paragraf yang tidak memiliki keterpaduan gagasan yang mewakili topik akan menyulitkan pembaca dalam memahami isi informasi yang ingin disampaikan penulisnya. Satu atau dua kalimat yang dinyatakan pada paragraf tersebut haruslah merupakan hal penting yang harus dipahami pembaca. Oleh karena itu, mengenali gagasan utamanya berarti memahami keseluruhan isi paragraf, yang berarti pula itulah topiknya.

Membaca pada hakikatnya adalah kegiatan memahami pesan penulis. Gagasan penulis dalam sebuah bacaan dapat berupa gagasan utama/pokok dan gagasan penjelas. Gagasan penulis pada taraf yang lebih kecil tampak pada gagasan dalam paragraf. Pengenalan terhadap gagasan pokok dan gagasan penjelas merupakan hal sangat penting dalam membaca. Kemampuan seseorang dalam mengenali suatu gagasan dalam sebuah paragraf akan sangat mempengaruhi pemahamannya terhadap isi paragraf tersebut.

Arti pemahaman adalah kemampuan atau keterampilan menangkap pengetahuan dari informasi yang disajikan dalam bentuk tertulis. Kegiatan membaca pemahaman berarti keterampilan dalam memperoleh arti dari teks yang dibaca. Tarigan (2008, p.12) mengungkapkan bahwa membaca yang bersifat pemahaman diantaranya mencakup aspek memahami pengertian sederhana (leksikal, gramatikal, retorikal), memahami signifikansi atau makna (maksud dan tujuan), dan evaluasi (isi dan bentuk), serta kecepatan membaca yang fleksibel. Membaca pemahaman berkaitan erat dengan usaha dan kemampuannya mengingat bahan yang dibaca dan memahami hal-hal penting dalam teks. Dalam kegiatan membaca, untuk tujuan tercapainya sebuah pemahaman tentu ada beberapa komponen yang harus dikuasai. Dengan menguasai komponen-komponen tersebut, pembaca akan mampu menuju kepada sebuah pemahaman dalam kegiatan membacanya. Hal-hal yang diperlukan untuk pemahaman adalah menguasai perbendaharaan kata, akrab dengan struktur dasar dalam penulisan seperti kalimat, paragraf dan ciri kebahasaan lain. Alex \& Achmad (2010, p.93) mengatakan bahwa "pembaca yang baik di antaranya memiliki ketajaman pikiran, pengetahuan kebahasaan dalam hal ini pengetahuan semantik, dan kemampuan menginterpresikan bahan bacaan yang sesuai dengan pikiran penulis".

Dalam upaya memperoleh pemahaman dalam teks, pembaca dapat menggunakan bantuan strategi tertentu. Strategi yang berkaitan erat dengan faktor-faktor yang terlibat dalam pemahaman, yaitu pembaca dan teks konteks. Faktor keterlibatan pembaca dalam memahami apa yang tersurat maupun tersirat diantaranya; pemusatan perhatian (konsentrasi), pengetahuan tentang dunia, pengalaman masa lalu dan memori. Selain hal tersebut, dibutukkan pula latihan, teknik, dan strategi membaca yang tepat, dengan meningkatkan kemampuan membaca yang melibatkan peran dan kekuatan otak sebagai pusat fungsi bahasa. Arifudin (2010, p.297) mengungkapkan, "membaca sebagai suatu keterampilan berbahasa, juga memerlukan latihan agar kecepatan dan ketepatannya dalam menangkap pesan yang tertulis dalam teks yang sedang dibacanya meningkat".

Pada dasarnya strategi membaca menggambarkan bagaimana pembaca memproses bacaan sehingga memperoleh pemahaman terhadap bacaan. Terdapat teori strategi membaca pemahaman yang dikenal dengan prosedur bottom-up dan prosedur top-down. Membaca dengan model bottom-up adalah dengan melakukan pemrosesan yang melibatkan ketepatan, rincian, dan rangkaian persepsi dan identifikasi huruf-huruf, kata-kata, pola ejaan dan unit bahasa lainnya. Intinya, dalam membaca untuk dapat memahami bacaan harus mengenali huruf. Membaca dengan model top-down adalah membaca dengan memanfaatkan pengetahuan-pengetahuan yang dimilikinya untuk memahami kata bahkan kalimat sesuai konteksnya. Dalam arti, untuk mencapai pemaknaan bacaan seorang pembaca dapat menggunakan kemampuan ber- 


\section{LingTera, 3 (1), May 2016 - 115 \\ Tjatur Marti Susilawati, Suhardi}

bahasa yang dimilikinya, misalnya penguasaan semantik dan sintaksis.

Banyaknya masalah yang teridentifikasi berkaitan dengan penguasaan kosakata dan ketepatan menemukan gagasan dengan keterampilan membaca pemahaman masalah dalam penelitian ini dirumusan menjadi tiga yaitu (1) Apakah ada hubungan antara penguasaan kosakata dengan keterampilan membaca pemahaman? (2) Apakah ada hubungan antara ketepatan menemukan gagasan dengan keterampilan membaca pemahaman? (3) Apakah ada hubungan antara penguasaan kosakata dan ketepatan menemukan gagasan dengan keterampilan membaca pemahaman?

Tujuan penelitian ini untuk mengetahui hubungan antara penguasaan kosakata dengan keterampilan membaca pemahaman, mengetahui hubungan antara ketepatan menemukan gagasan dengan keterampilan membaca pemahaman, mengetahui hubungan antara penguasaan kosakata dan ketepatan menemukan gagasan secara bersama-sama dengan keterampilan membaca pemahaman. Adapun manfaat yang diberikan oleh penelitian ini diharapkan dapat memberikan manfaat baik secara teoretis maupun praktis.

Secara teoretis, hasil penelitian ini diharapkan dapat memperkuat teori yang sudah ada tentang membaca pemahaman, penguasaan kosakata dan bagaimana menemukan gagasan sebuah teks, sehingga dapat memperkaya khazanah pengetahuan tentang ketiga hal tersebut. Bagi guru penelitian ini bisa sebagai referensi untuk melatihkan kegiatan membaca terutama membaca pemahaman. Dengan bekal tersebut, diharapkan siswa memiliki kemampuan yang lebih baik dalam kegiatan membaca sehingga akan memperoleh pengetahuan dan wawasan yang luas yang bermanfaat bagi kehidupannya.

\section{METODE}

\section{Jenis Penelitian}

Penelitian ini adalah penelitian ex-post facto. Dengan kata lain, penelitian ini bersifat noneksperimental. Data dikumpulkan setelah semua kejadian yang dipermasalahkan sudah ada, kemudian ditelusuri untuk mencari sebab-sebab yang saling berhubungan serta makna hubungan tersebut.

\section{Tempat danWaktu Penelitian}

Penelitian ini dilaksanakan di SMP/MTs di Kecamatan Tegalrejo Kabupaten Magelang.
Adapun waktu pelaksanaan pengumpulan data pada bulan November 2013.

\section{Populasi dan Sampel}

Populasi penelitian ini adalah seluruh siswa kelas VIII SMP/MTs di Kecamatan Kabupaten Magelang tahun pelajaran 2013/2014. Jumlah SMP dan MTs yang terdapat di Kecamatan Tegalrejo Kabupaten Magelang sebanyak 6 sekolah. SMP negeri sebanyak dua sekolah, SMP swasta sebanyak dua sekolah, dan MTs sebanyak dua sekolah. Keseluruhan jumlah populasi penelitian ini adalah 818 siswa.

Teknik pengambilan sampel secara random sampling menggunakan teknik proportional cluster random sampling. Besarnya sampel penelitian sebanyak 262 siswa.

\section{Prosedur}

Penelitian ini merupakan penelitian kuantitatif yang meneliti hubungan penguasaan kosakata dan ketepatan menemukan gagasan dengan keterampilan membaca pemahaman. Penelitian dilakukan dengan meminta responden yang merupakan sampel penelitian ini untuk memberikan jawaban atas soal-soal yang diberikan sebagai data penelitian. Adapun soal-soal yang diberikan sehubungan dengan penguasan kosakata, ketepatan menemukan gagasan dan keterampilan membaca pemahaman.

\section{Data, Instrumen, dan Teknik Pengumpulan Data}

Data yang dihasilkan dari penelitian ini ada tiga macam, yaitu data tentang penguasaan kosakata, data tentang ketepatan menemukan gagasan dan data tentang keterampilan membaca pemahaman. Ketiga data tersebut disajikan dalam bentuk distribusi frekuensi dan visualisasi grafik. Untuk mendapatkan ketiga data tersebut, instrumen tes diberikan kepada responden yang menjadi sampel penelitian untuk dikerjakan sebaik mungkin. Instrumen yang digunakan adalah tes berbentuk pilihan ganda tentang penguasaan kosakata, ketepatan menemukan gagasan dan keterampilan membaca pemahaman.

\section{HASIL DAN PEMBAHASAN}

Data yang dideskripsikan pada penelitian ini meliputi deskripsi data seluruh variabel penelitian maupun data setiap variabel yang meliputi data penguasaan kosakata $\left(\mathrm{X}_{1}\right)$, data ketepatan menemukan gagasan $\left(\mathrm{X}_{2}\right)$, dan data keterampilan membaca pemahaman (Y). Deskripsi data 


\section{LingTera, 3 (1), May 2016 - 116 \\ Tjatur Marti Susilawati, Suhardi}

penelitian untuk keseluruhan variabel dalam penelitian ini termuat pada tabel berikut.

Tabel 1. Deskripsi Data Hasil Penelitian

\begin{tabular}{cccc}
\hline Statistik & $\left(\mathbf{X}_{\mathbf{1}}\right)$ & $\left.\mathbf{( X}_{\mathbf{2}}\right)$ & $\mathbf{( Y )}$ \\
\hline Nvalid & 262 & 262 & 262 \\
Mean & 11.0420 & 6.0267 & 10.8435 \\
Median & 11.0000 & 6.0000 & 11.0000 \\
Mode & 12.00 & 6.00 & 10.00 \\
SD & 2.41208 & 1.22192 & 3.55719 \\
Min & 5.00 & 3.00 & 1.00 \\
Max & 18.00 & 10.00 & 19.00 \\
\hline
\end{tabular}

Skor Penguasaan Kosakata (( $\left.\mathrm{X}_{1}\right)$

Data tentang skor penguasan kosakata $\left(\mathrm{X}_{1}\right)$ diperoleh rentang skor antara 5 sampai dengan 18, rata-rata sebesar 11,0420, simpangan baku sebesar 2,41208. Median sebesar 11,00 dan modus terletak pada skor 12,00. Pengelompokan menurut kategori dengan rentang skor 15 sampai dengan 18 kategori sangat baik, skor 11 sampai dengan 14 kategori baik, skor 7 sampai dengan 10 kategori cukup/sedang, skor 3 sampai dengan 6 kategori kurang, dan kategori sangat kurang bila jumlah pemerolehan skor < 3. Kategori skor hasil tes penguasaan kosakata ini dapat dilihat pada Tabel 2.

Tabel 2. Frekuensi Kategori Penguasaan Kosakata

\begin{tabular}{cccc}
\hline Interval & $\mathbf{F}$ & $\mathbf{\%}$ & Kategori \\
\hline $15-18$ & 18 & 6,9 & Sangat Baik \\
$12-14$ & 94 & 35,7 & Baik \\
$8-11$ & 135 & 51,8 & Sedang \\
$4-7$ & 15 & 5,7 & Kurang \\
$\leq 3$ & 0 & 0 & Sangat Kurang \\
\hline
\end{tabular}

Pada Tabel 2 dapat diketahui bahwa 6,9\% responden memiliki penguasaan kata sangat baik, $35,7 \%$ responden penguasaan kosakatanya baik, $51,8 \%$ responden penguasaan kosakatanya cukup/sedang, dan $5,7 \%$ responden memiliki penguasaan kosakata kurang. Dengan demikian, siswa yang terbanyak adalah memiliki penguasaan kosakata cukup/sedang. Kategorisasi tentang skor penguasaan kosakata tersebut dapat digambarkan dalam Gambar 1.

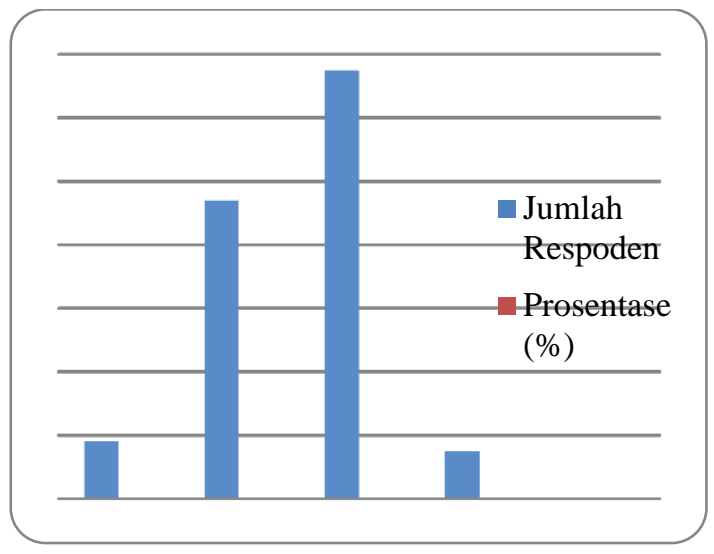

Gambar 1. Diagram Kategorisasi Penguasaan Kosakata

Skor Ketepatan Menemukan Gagasan $\left(\mathrm{X}_{2}\right)$

Hasil analisis data skor kemampuan menemukan gagasan $\left(\mathrm{X}_{2}\right)$ menunjukkan bahwa rentang skor tingkat kemampuan menemukan gagasan antara 3 sampai dengan 10, rata-rata (Ё) 6,0267, simpangan baku (SD) sebesar 1,2299, median sebesar 6,00. Modus terletak pada skor 6,00. Pengelompokan kategori rentang skor variabel ini dapat dilihat pada Tabel 3.

Tabel 3. Frekuensi Kategori Ketepatan Menemukan Gagasan

\begin{tabular}{cccc}
\hline Interval & $\mathbf{F}$ & $\boldsymbol{\%}$ & Kategori \\
\hline $8-10$ & 22 & 8,4 & Sangat Baik \\
$6-7$ & 164 & 63 & Baik \\
$4-5$ & 73 & 27,5 & Sedang \\
$2-3$ & 3 & 1,1 & Kurang \\
$<2$ & 0 & 0 & Sangat Kurang \\
\hline
\end{tabular}

Pada Tabel 3 dapat diketahui bahwa 8,4\% responden memiliki kemampuan menemukan gagasan sangat baik, 63\% responden memiliki kemampuan menemukan gagasan dalam kategori baik, 27,5\% responden memiliki kemampuan menemukan gagasan dengan kategori sedang, dan siswa yang memiliki kemampuan menemukan gagasan dengan kategori kurang sebanyak $1,1 \%$ responden. Berdasarkan hasil pada Tabel 3 dapat dikatakan bahwa sebagian besar siswa kelas VIII SMP/MTs di Kecamatan Kabupaten Magelang tahun pelajaran 2013/2014 memiliki kemampuan yang baik dalam menemukan gagasan.

Kategorisasi tentang skor ketepatan menemukan gagasan tersebut dapat digambarkan dalam diagram Gambar 2. 


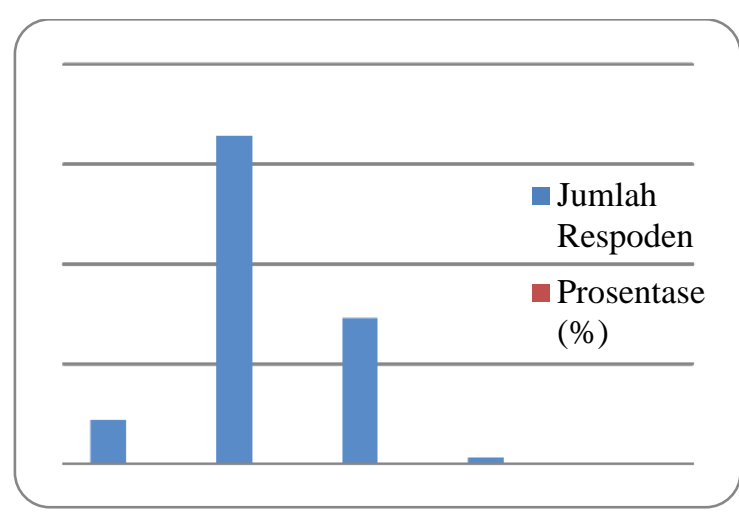

Gambar 2. Diagram Kategorisasi Ketepatan Menemukan Gagasan

Skor Keterampilan Membaca Pemahaman (Y)

Data skor keterampilan membaca pemahaman (Y) ditunjukkan pada Tabel 4. Hasil analisis menunjukkan rentang skor tingkat keterampilan membaca pemahaman antara sampai 1 dengan 19 , rata-rata $(\ddot{X}) 10,8435$, simpangan ba$\mathrm{ku}(\mathrm{SD})$ sebesar 3,5571, median sebesar 11,00, dan modus terletak pada skor 10,00. Rentang skor variabel ini terdiri atas kategori sangat baik, kategori baik, sedang, kategori kurang dan kategori sangat kurang. Tabel 4 menyajikan kategorisasi skor hasil tes keterampilan membaca pemahaman.

Tabel 4. Frekuensi Kategori Keterampilan Membaca Pemahaman

\begin{tabular}{cccc}
\hline Interval & F & \% & Kategori \\
\hline $16-21$ & 28 & 10,6 & Sangat Baik \\
$11-15$ & 107 & 40,8 & Baik \\
$6-10$ & 111 & 42,3 & Sedang \\
$1-5$ & 16 & 6,1 & Kurang \\
$<1$ & 0 & 0 & Sangat Kurang \\
\hline
\end{tabular}

Pada Tabel 4 diketahui bahwa 10,6\% responden memiliki keterampilan membaca pemahaman sangat baik, 40,8\% rsponden memiliki keterampilan membaca pemahaman dengan kategori baik, 42,3\% responden memiliki keterampilan membaca pemahaman dengan kategori sedang, dan keterampilan membaca pemahaman dengan kategori kurang dimiliki $6,1 \%$ responden. Dengan demikian, keterampilan membaca siswa termasuk dalam kategori sedang.

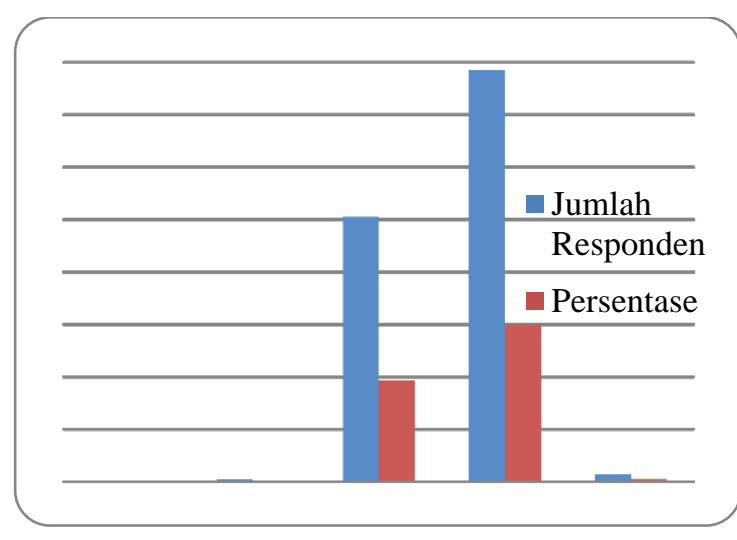

Gambar 3. Diagram Frekuensi Kategori

Keterampilan Membaca Pemahaman

\section{Analisis Data}

Bagian ini akan menyajikan dua hal pokok dari analisis data yaitu uji prasyarat analisis dan uji hipotesis.

\section{Uji Prasyarat Analisis}

Hasil Uji Normalitas

Distribusi data dikategorikan normal apabila memiliki taraf signifikansi ( $p$ value $)>0,05$. Hasil uji normalitas data penelitian ini disajikan pada Tabel 5.

Tabel 5. Hasil Uji Normalitas

\begin{tabular}{lrr}
\hline & \multicolumn{2}{c}{ Unstandardized } \\
Residual
\end{tabular}

Data pada Tabel 5 menunjukkan bahwa nilai residual dengan asymp sig. (2-tailed) sebesar 0,232. Ini berarti, bahwa signifikansi lebih besar dari $\rho$ yang telah ditentukan $(0,05)$. Dengan demikian, 0,232>0,05, artinya seluruh data berdistribusi normal.

Hasil Uji Linearitas Data

Hasil pengujian data dipresentasikan oleh gambar grafik yaitu berupa garis yang mengarah ke kanan atas. Hal ini menunjukkan bahwa variabel bebas penguasaan kosakata dan ketepatan menemukan gagasan terdapat hubungan linier dengan variabel terikat keterampilan membaca 


\section{LingTera, 3 (1), May 2016 - 118 \\ Tjatur Marti Susilawati, Suhardi}

pemahaman. Dengan demikian, dapat dikatakan bahwa antara penguasaan kosakata dan ketepatan menemukan gagasan terdapat hubungan linier. Hasil uji linieritas variabel penguasaan kosakata, ketepatan menemukan gagasan dan keterampilan membaca pemahaman dapat dilihat pada gambar berikut ini.

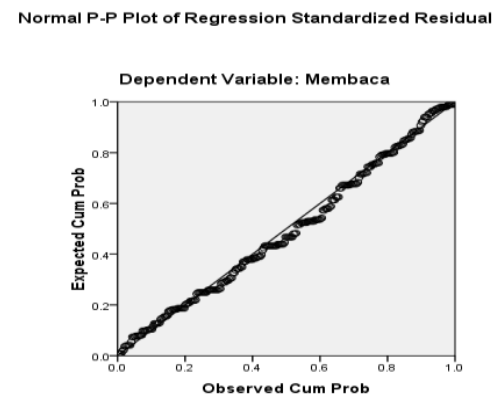

Gambar 4. Grafik Hasil Uji Linieritas Data

Hasil Uji Multikolinearitas

Uji multikolinearitas pada penelitian ini menggunakan Variance Inflaction Factor (VIF). Multikolinearitas data terjadi jika nilai VIF lebih besar dari 10. Berdasarkan hasil uji multikolinearitas yang telah dilakukan, output nilai VIF $<10$, maka data tidak terjadi multikolinearitas. Hasil selengkapnya dapat dilihat pada Tabel 6 berikut ini.

Tabel 6. Rangkuman Hasil Uji Multikolinieritas

\begin{tabular}{ccc}
\hline $\begin{array}{c}\text { Variabel } \\
\text { Bebas }\end{array}$ & VIF & Kesimpulan \\
\hline $\mathrm{X}_{1}$ & 3,970 & $\begin{array}{c}\text { Tidak terjdi } \\
\text { Multikolinieritas } \\
\text { Tidak terjdi } \\
\text { Multikolinieritas }\end{array}$ \\
\hline
\end{tabular}

\section{Uji Hipotesis}

Hubungan Penguasaan Kosakata dengan Keterampilan Membaca Pemahaman

Hasil perhitungan untuk pengujian hipotesis "ada hubungan antara penguasaan kosakata dengan keterampilan membaca pemahaman" ditemukan $\mathrm{t}_{\text {hitung }}=12,495$ dengan signifikansi 0,000 , karena $\rho$ lebih besar dari signifikansinya yaitu $0,05>0,000$, maka $\mathrm{H}_{\mathrm{o}}$ ditolak, artinya ada hubungan positif dan signifikan antara penguasaan kosakata dengan keterampilan membaca pemahaman. Hasil analisis regresi sederhana secara ringkas disajikan pada Tabel 7.
Tabel 7. Hasil Uji Korelasi $\mathrm{X}_{1}-\mathrm{Y}$

\begin{tabular}{cccccc}
\hline Model & $\mathbf{R}$ & $\mathbf{R}^{2}$ & $\begin{array}{c}\text { Adj. } \mathbf{R} \\
\text { Square }\end{array}$ & $\mathbf{t}_{\text {hit }}$ & Sig. \\
\hline $\mathrm{X}_{1}$ & $.613^{\mathrm{a}}$ & .375 & .373 & 12.495 & $.000^{\mathrm{a}}$ \\
\hline
\end{tabular}

Hubungan Ketepatan Menemukan Gagasan dengan Keterampilan Membaca Pemahaman

Hasil perhitungan untuk pengujian hipotesis "ada hubungan antara ketepatan menemukan gagasan dengan keterampilan membaca pemahaman" ditemukan $\mathbf{t}_{\text {hitung }}=13,471$ dengan signifikansi 0,00 , karena plebih besar dari signifikansinya yaitu $0,05>0,00$, maka $\mathrm{H}_{\mathrm{o}}$ ditolak, artinya ada hubungan positif dan signifikan antara ketepatan menemukan gagasan dengan keterampilan membaca pemahaman. Hasil analisis regresi sederhana secara ringkas disajikan pada Tabel 8.

Tabel 8. Hasil Uji Regresi $\mathrm{X}_{2}-\mathrm{Y}$

\begin{tabular}{cccccc}
\hline Model & $\mathbf{R}$ & $\mathbf{R}^{\mathbf{2}}$ & $\begin{array}{c}\text { Adj. } \mathbf{R} \\
\text { Square }\end{array}$ & $\mathbf{t}_{\text {hit }}$ & Sig. \\
\hline $\mathrm{X}_{2}$ & $.641^{\mathrm{a}}$ & .411 & .409 & 13.471 & $.000^{\mathrm{a}}$ \\
\hline
\end{tabular}

Hubungan Penguasaan Kosakata, Ketepatan Menemukan Gagasan dengan Keterampilan Membaca Pemahaman

Dari hasil perhitungan untuk pengujian hipotesis "ada hubungan antara penguasaan kosakata, ketepatan menemukan gagasan dan keterampilan membaca pemahaman" ditemukan $\mathrm{F}_{\text {hitung }}=95,483$ dengan signifikansi 0,00. Karena $\rho$ lebih besar dari signifikansinya, yaitu $0,05>0,00$, maka Ho ditolak, dan $\mathrm{H}_{\mathrm{a}}$ diterima, artinya ada hubungan positif dan signifikan antara penguasaan kosakata, ketepatan menemukan gagasan secara bersama-sama dengan keterampilan membaca pemahaman. Hasil analisis regresi Ganda secara ringkas disajikan pada Tabel 7.

Tabel 7. Hasil Uji Regresi Ganda $X_{1}, X_{2}-Y$

\begin{tabular}{cccccc}
\hline Model & $\mathrm{R}$ & $\mathrm{R}^{2}$ & $\begin{array}{c}\text { Adj. } \mathrm{R} \\
\text { Square }\end{array}$ & $\mathrm{F}_{\text {hit }}$ & Sig. \\
\hline $\mathrm{X}_{1}, \mathrm{X}_{2}$ & $.651^{\mathrm{a}}$ & .424 & .420 & 95.483 & $.000^{\mathrm{a}}$ \\
\hline
\end{tabular}

Untuk memastikan apakah variable independen yang terdapat dalam persamaan tersebut secara individu berpengaruh terhadap nilai variable dependen, maka dilakukan uji parsial atau uji koefisien regresi dengan melakukan pengujian hipotesis terhadap koefisien regresi semua variable independen. Hasil uji parsial disajikan pada Tabel 8. 
Tabel 8. Hasil Uji Parsial $\mathrm{X}_{1} \cdot \mathrm{X}_{2}-\mathrm{Y}$ dan $\mathrm{X}_{2} \cdot \mathrm{X}_{1}-\mathrm{Y}$

\begin{tabular}{|l|l|l|l|l|}
\hline & & & & \\
\hline & & & & \\
\hline & & & & \\
\hline
\end{tabular}

\begin{tabular}{lcccc}
\hline $\begin{array}{c}\text { Model Unstandardized } \\
\text { Coefficients } \\
\text { Beta }\end{array}$ & $\begin{array}{c}\text { Zero- } \\
\text { order }\end{array}$ & Partial & Part \\
\hline (constant) & -6.10 & & & \\
Kosakata & .340 & .613 & .151 & .116 \\
Gagasan & 1.278 & .641 & .281 & .222 \\
\hline
\end{tabular}

Berikut ini rumusan hipotesis untuk pengujian koefisien regresi atau uji parsial.

$\begin{array}{ll}\mathrm{H}_{0}: b_{1}=0 & \text { lawan } \mathrm{H}_{\mathrm{a}}: b_{1} \# 0 \\ b_{2}=0 & b_{2} \# 0\end{array}$

Berdasarkan hasil pengujian dua sisi menggunakan $\alpha / 2$ penentuan $t_{\text {tabel }}$ dengan tingkat signifikansi $5 \%(\alpha=0,05)$ dan degree of freedom $(d f)=260$, maka nilai kritis untuk pengujian ini adalah $\mathrm{t}_{(260 ; 0,05)}=1,650735$. Nilai $\mathrm{t}_{\text {test }}$ masing-masing koefisien regresi berdasarkan hasil perhitungan diperoleh $\mathrm{t}_{\text {test }}$ untuk $b_{1}$ adalah 2,451 dan $\mathrm{t}_{\text {test }}$ untuk $b_{2}$ adalah 4,706. Artinya, nilai koefisien regresi dari setiap persamaan regresi berbeda dengan 0 (nol). Dengan demikian, berdasarkan letak nilai $t_{\text {test }}$ koefisien regresi pada kurva normal, $t_{\text {test }}$ terletak di daerah penolakan $\mathrm{H}_{0}$, maka dapat dikatakan $\mathrm{H}_{0}$ ditolak dan $\mathrm{H}_{\mathrm{a}}$ diterima. Hal ini dapat dikatakan, bahwa variabel independen tersebut berpengaruh terhadap nilai dependen, sehingga disimpulkan, bahwa variabel independen $\mathrm{X}_{1}$ dan $\mathrm{X}_{2}$ berpengaruh terhadap variabel dependen $(\mathrm{Y})$.

Untuk mengetahui pengaruh semua variabel independen terhadap variabel dependen dilakukan uji simultan menggunakan distribusi $\mathrm{F}$ dengan membandingkan nilai kritis $\mathrm{F}$ dengan nilai $\mathrm{F}_{\text {test }}$ atau $\mathrm{F}_{\text {ratio }}$ yang terdapat padatabel Analysis of Variance (ANOVA). Rumusan hipotesis untuk pengujian ini adalah sebagai berikut:

$\mathrm{H}_{0}$ : Variasi perubahan nilai independen tidak dapat menjelaskan variasi perubahan nilai variable dependen

$\mathrm{H}_{\mathrm{a}}$ : Variasi perubahan nilai variable independen dapat menjelaskan variasi perubahan nilai variable dependen

Nilai kritis dalam distribusi $\mathrm{F}$ dengan tingkat signifikansi $5 \%(\alpha=0,05)$ dan degree of freedom $(d f)$ adalah $\mathrm{F}_{(2 ; 259)}=3,030$. Nilai $\mathrm{F}_{\text {test }}$ ha- sil pengujian diperoleh $\mathrm{F}_{\text {ratio }}=95,483$. Dari hasil pengujian tersebut dapat dikatakan bahwa $\mathrm{F}_{\text {test }}$ > $\mathrm{F}_{\text {tabel }}$ atau $\mathrm{F}_{\text {test }}$ berada di daerah penolakan $\mathrm{H}_{0}$ dan menerima $\mathrm{H}_{a}$, sehingga dapat disimpulkan bahwa variasi perubahan nilai variabel dependen dapat dijelaskan oleh variasi perubahan nilai semua variabel independen. Artinya, semua variabel independen $\left(\mathrm{X}_{1}\right.$ dan $\mathrm{X}_{2}$ ) secara bersamasama atau secara simultan dapat berpengaruh terhadap variabel dependen $(\mathrm{Y})$.

\section{Pembahasan}

Hubungan Penguasaan Kosakata dengan Keterampilan Membaca Pemahaman.

Hipotesis yang berbunyi "ada hubungan penguasaan kosakata dengan keterampilan membaca pemahaman siswa kelas VIII SMP/ MTs di Kecamatan Tegalrejo Kabupaten Magelang" tersebut terbukti signifikan.

Hasil analisis korelasi penguasaan kosakata dengan keterampilan membaca pemahaman menunjukkan nilai koefisien korelasi sebesar 0,613 dan $\rho<0,05$, yang berarti penguasaan kosakata dengan keterampilan membaca pemahaman memiliki hubungan positif dan signifikan. Hasil analisis regresi menunjukkan bahwa besarnya kontribusi penguasaan kosakata terhadap kemampuan membaca pemahaman 0,373. hasil analisis korelasi parsial menghasilkan koefisien korelasi sebesar 0,151 , yang berarti hasil ini lebih kecil dari hasil analisis korelasi secara individu antara penguasaan kosakata dengan keterampilan membaca pemahaman. Hal ini diartikan, bahwa penguasaan kosakata akan memberikan pengaruh yang lebih besar terhadap keterampilan membaca pemahaman, jika hubungan tersebut tanpa dikontrol oleh ketepatan menemukan gagasan. Demikian pula sebaliknya, jika dibandingkan dengan uji korelasi yang dilakukan dengan pengontrolan.

Hasil penelitian ini membuktikan bahwa semakin baik penguasaan kosakata, akan diikuti semakin tinggi keterampilan membaca pemahaman siswa kelas VIII SMP/MTs di Kecamatan Tegalrejo Kabupaten Magelang.

Hubungan antara Kemampuan Menemukan Gagasan dengan Keterampilan Membaca Pemahaman.

Hasil analisis korelasi ketepatan menemukan gagasan dengan keterampilan membaca pemahaman menunjukkan nilai koefisien korelasi sebesar 0,641 dan $\rho<0,05$, yang berarti ketepatan menemukan gagasan dan keterampilan 


\section{LingTera, 3 (1), May 2016 - 120 \\ Tjatur Marti Susilawati, Suhardi}

membaca pemahaman memiliki hubungan positif dan signifikan. Hasil analisis regresi menunjukkan bahwa besarnya kontribusi ketepatan menemukan gagasan terhadap keterampilan membaca pemahaman 0,409. Hasil analisis korelasi parsial menghasilkan koefisien korelasi sebesar 0,281, yang berarti hasil ini lebih kecil dibandingkan dengan hasil analisis korelasi secara individu ketepatan menemukan gagasan dengan keterampilan membaca pemahaman. Hal ini dapat diartikan, bahwa ketepatan menemukan gagasan akan memberikan pengaruh yang lebih besar terhadap keterampilan membaca pemahaman, jika hubungan tersebut tanpa dikontrol oleh penguasaan kosakata.

Dengan demikian, dugaan bahwa ada hubungan kemampuan menemukan gagasan dengan keterampilan membaca pemahaman siswa kelas VIII SMP/MTs di Kecamatan Tegalrejo Kabupaten Magelang terbukti. Hal ini ditunjukkan dengan hasil analisis data pada pengujian hipotesis yang positif dan signifikan.

Hubungan Penguasaan Kosakata dan Ketepatan Menemukan Gagasan dengan Keterampilan Membaca Pemahaman.

Hasil analisis korelasi antara penguasaan kosakata dan ketepatan menemukan gagasan secara bersama-sama dengan keterampilan membaca pemahaman menunjukkan nilai koefisien korelasi sebesar 0,651 dan $\rho<0,05$, yang berarti penguasaan kosakata dan ketepatan menemukan gagasan dengan keterampilan membaca pemahaman memiliki hubungan positif dan signifikan. Hasil analisis regresi menunjukkan bahwa besarnya kontribusi penguasaan kosakata terhadap keterampilan membaca pemahaman sebesar 0,420.

Dengan demikian, dapat disimpulkan bahwa penguasaan kosakata dan ketepatan menemukan gagasan dengan keterampilan membaca pemahaman siswa kelas VIII SMP/MTs di Kecamatan Tegalrejo Kabupaten Magelang terbukti memiliki hubungan positif dan signifikan. Berdasarkan hasil hubungan tersebut, semakin tinggi penguasaan kosakata $\left(\mathrm{X}_{1}\right)$, dan ketepatan menemukan gagasan $\left(\mathrm{X}_{2}\right)$ semakin tinggi pula keterampilan membaca pemahaman (Y).

Berdasarkan perhitungan koefisien determinasi $\left(\mathrm{R}^{2}\right)$ diperoleh hasil nilai $\mathrm{R}^{2}=0,424$ dan adjusted $\mathrm{R}$ square sebesar 0,420 . Hasil ini dapat diartikan bahwa pengaruh bersih variabel $\mathrm{X}$ (independent) terhadap variabel Y (dependent) sebesar $42 \%$, sedangkan sisanya 58\% lainnya dipengaruhi oleh variabel lain. Dengan demi- kian, dapat disimpulkan bahwa masih terdapat variabel-variabel selain penguasaan kosakata dan ketepatan menemukan gagasan yang berpengaruh terhadap keterampilan membaca pemahaman.

\section{SIMPULAN DAN SARAN}

\section{Simpulan}

Ada hubungan positif dan signifikan antara penguasaan kosakata dengan keterampilan membaca pemahaman siswa kelas VIII SMP/ MTs di Kecamatan Tegalrejo Kabupaten Magelang dengan koefisien korelasi sebesar $0,613, \mathrm{R}^{2}$ sebesar 0,375, adjusted $R$ 0,373 dengan $\rho<0,05$, dan koefisien korelasi secara parsial sebesar 0,151 . Penguasaan kosakata diprediksikan memberi pengaruh terhadap keterampilan membaca pemahaman sebesar 37,3\%, bila hubungan tersebut tanpa adanya pengontrolan ketepatan menemukan gagasan, sedangkan hubungan penguasaan kosakata dengan keterampilan membaca pemahaman dikontrol oleh variabel ketepatan menentukan gagasan besarnya korelasi adalah 0,151 .

Ada hubungan positif dan signifikan antara ketepatan menemukan gagasan dengan keterampilan membaca pemahaman siswa kelas VIII SMP/MTs di Kecamatan Tegalrejo Kabupaten Magelang dengan koefisien korelasi sebesar 0,641, $\mathrm{R}^{2}$ sebesar 0,411, adjusted $\mathrm{R}$ sebesar 0,409 atau 40,9\% dengan $\rho<0,05$, dan koefisien korelasi secara parsial sebesar 0,281. Ketepatan menemukan gagasan diprediksikan memberi pengaruh terhadap keterampilan membaca pemahaman sebesar $40,9 \%$, bila hubungan tersebut tanpa adanya pengontrolan penguasaan kosakata, sedangkan hubungan ketepatan menemukan gagasan dengan keterampilan membaca pemahaman dikontrol oleh variabel penguasaan kosakata besarnya korelasi adalah 0,281.

Ada hubungan positif dan signifikan antara penguasaan kosakata dan ketepatan menemukan gagasan secara bersama-sama dengan keterampilan membaca pemahaman dengan $\mathrm{R}$ sebesar $0,651, \mathrm{R}^{2}$ sebesar 0,424 , dan adjusted $\mathrm{R}$ square sebesar 0,420 dengan signifikansi $\rho$ < 0,05 . Sumbangan penguasaan kosakata dan ketepatan menemukan gagasan terhadap keterampilan membaca pemahaman sebesar $42 \%$, sedangkan sisanya sebesar $58 \%$ dipengaruhi oleh variabel lain, selain penguasaan kosakata dan ketepatan menemukan gagasan. Oleh karena itu, diperlukan penelitian lain selain variabel-variabel tersebut yang dimungkinkan ada hubungan 


\section{LingTera, 3 (1), May 2016 - 121}

Tjatur Marti Susilawati, Suhardi

dengan keterampilan membaca pemahaman. Dari hipotesis yang diajukan bahwa penguasaan kosakata dan ketepatan menemukan gagasan dengan keterampilan membaca pemahaman siswa kelas VIII SMP/MTs di Kecamatan Tegalrejo Kabupaten Magelang terbukti memiliki hubungan positif dan berpengaruh secara signifikan.

\section{Saran}

Untuk meningkatkan keterampilan membaca perlu didukung sepenuhnya oleh guru, terutama guru bidang studi bahasa Indonesia. Hal ini perlu dilakukan agar siswa mempunyai keterampilan membaca pemahaman yang tinggi sehingga dapat mendukung kemampuan dalam memahami informasi tertulis. Untuk meningkatkan penguasaan kosakata siswa perlu dilakukan oleh guru melalui kegiatan pembelajaran di sekolah baik melalui mata pelajaran bahasa Indonesia maupun mata pelajaran yang lain. Untuk meningkatkan kemampuan siswa dalam menemukan gagasan dengan tepat dapat dilakukan melalui kegiatan melatih siswa menemukan gagasan pokok dan gagasan penjelas paragraf teks wacana. Para pembaca dapat mengembangkan penelitian ini lebih lanjut dengan membahas konsep yang lain misalnya penguasaan struktur bahasa, kecepatan membaca dan sebagainya, yang dapat meningkatkan keterampilan membaca pada diri siswa.

\section{DAFTAR PUSTAKA}

Alex \& Achmad, H. (2010). Bahasa Indonesia untuk perguruan tinggi. Jakarta: Kencana Prenada Media Group

Arifudin. (2010). Neuropsikolinguistik. Jakarta: Raja Grafindo Persada

Nation, I. S. P. (2001). Learning vocabulary in another language. Cambridge: Cambridge University Press

Harjasujana \& Mulyati, Y (1997). Membaca 2. Jakarta: Depdikbud, Ditjen, Dikdasmen

Nurgiyantoro, B. (2012). Penilaian pembelajaran bahasa. Yogyakarta: BPFE

Rahardi, K. (2009). Penyuntingan bahasa Indonesia untuk karang mengarang. Jakarta: Erlangga

Rohmadi, M. \& Nasucha, Y. (2010). Paragraf: pengembangan \& implementasi. Surakarta: Media Perkasa

Suryaman, M. (2012). Metodologi pembelajaran bahasa. Yogyakarta: UNY Press

Tarigan, H. G. (2008). Membaca sebagai suatu keterampilan berbahasa. Bandung: Angkasa. 